\title{
Exploratory Analysis on the Management of Agricultural Knowledge and Information by Smallholder Farmers in Kandy and Kurunegala Districts in Sri Lanka
}

\author{
C. Jayathilake ${ }^{1^{*}}$, U. Dissanayeke ${ }^{2}$, U. K. Jayasinghe-Mudalige ${ }^{3}$, J. Edirisinghe ${ }^{3}$, K. \\ Herath $^{3}$ and J. Lindara ${ }^{4}$
}

\begin{abstract}
The extent of farmer knowledge and availability of precise information in farming are considered as key driving forces in agriculture development that transform the livelihoods of farmers into one with increased household income stability and food security. However farmers who do not have free/subsidized and open/fair access to the vital agricultural information would, therefore, face severe difficulties in their attempt to achieve the goals of farming. The purpose of the study was to investigate the factors that trigger or hinder farmer access to agricultural knowledge and information. The smallholder export agricultural crop producers in Kandy \& Kurunegala districts in Sri Lanka were used as the case. A series of pre-tested structured questionnaire-based face-to-face interviews were carried out with

${ }^{1}$ ICT Center, Wayamba University of Sri Lanka, Makandura, Gonawila (NWP).

${ }^{2}$ Faculty of Agriculture, University of Peradeniya, Sri Lanka

${ }^{3}$ Faculty of Agriculture \& Plantation Management, Wayamba University of Sri Lanka, Makandura, Gonawila (NWP).

${ }^{4}$ Department of Export Agriculture, Peradeniya, Sri Lanka

*hackjayathilake@gmail.com

https://orcid.org/0000-0002-0629-6303
\end{abstract}

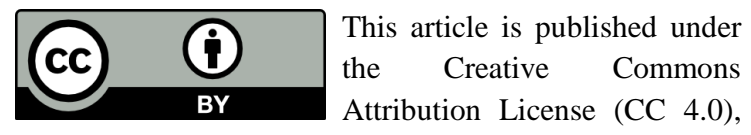

which permits unrestricted use, distribution, and reproduction in any medium provided the original work is properly cited. a cross-section of farmers to gather data and both descriptive and quantitative techniques, including Factor and Logistics Regression analysis, were employed to analyze the data. The results show that the level of acquisition of agricultural knowledge by farmers has a positive and negative relationship with the level of education and age of farmer, respectively. Amongst other factors, the farmers, in general, requested badly the valid and reliable agricultural information on a regular basis with regard to the market prices of inputs and outputs, credits/subsidies/loans etc. The inadequacy in information services and agricultural officers, limited infrastructure and insufficient funds/resources hinder farmer access to agricultural knowledge and information. The outcome of the analysis, overall, implies that the importance of developing appropriate packages to facilitate information sharing and knowledge mobilization to specific farming communities is in need with the right mix of market-based and regulatory incentives.

Keywords: Agricultural knowledge, Information management, Smallholder farmers

\section{INTRODUCTION}

Knowledge and information are vital in rural farm development, thus access to agricultural knowledge is the key for transforming the livelihoods of rural poor into a one with increased income stability and food security (Lwoga et al., 2011). 
Knowledge is filtered from information, or in other words, information is connected to knowledge through the data-informationknowledge hierarchy (Frické, 2009). Farmer empowerment needs to starts with information because it plays a pivotal role in increasing agricultural production and improving marketing and distribution strategies (Rehman et al., 2013). Further agricultural information is considered as a productive resource limiting and influencing the efficiency of production as it shapes farmers' decision making (Bawa and Bzugu, 2014). Therefore access to agricultural knowledge and information is vital for acquiring the skills and techniques required to improve farming practices, sustaining the environment and to optimize agricultural production.

According to Galadima (2014), the major constraints for farmers' to access into agricultural information in Nigeria, include irrelevant information, delay in information delivery, extension workers' personalities, language barriers, and lack of feedback mechanisms. According to Mtega et al. (2016), the limited number of demonstration plots, late delivery of information services, a limited number of agricultural extension agents, limited information about crop market and poor information communication technologies (ICTs) hindered access to agricultural knowledge among rice farmers in Tanzania. Lwevo et.al. (2014) mentioned that the cultural factors (i.e. language, religion, gender, etc.) influence access to agricultural extension while language was the key influential cultural factor.
To address the issue on inadequate access to agriculture knowledge, a strong link between agricultural research and farmers should be established. According to Nazari et al., (2011), the agricultural research institutions should introduce new technologies and developments, and further, care must be taken to assure that those reach the farmers' needs through effective extension and mass media channels. Conversely, if agricultural technologies and developments do not reach farmers adequately, the process of transforming agriculture and farmer livelihood development would remain impossible. Therefore, when formulating the policies on the development and dissemination of agricultural knowledge in a country more emphasis needs to be given on accessing knowledge.

Agriculture is the driving force for rural development in Sri Lanka and it contributes nearly $7.9 \%$ of the GDP of Sri Lankan economy. There is about 28.2\% Sri Lankan workforce involved in agricultural sector. Sri Lankan agriculture sector is dominated by smallholders, with over 64\% of the farming families' cultivation holdings of less than 0.8 hectares (Central Bank, 2015). There is an abundance of knowledge on agriculture in Sri Lanka that has been generated through various sources and institutions (e.g. universities, research stations and departments). Further, those are in different forms, e.g. printed matter, recorded and/or in cyberspace, or in the form of day-to-day communications on prevailing 'market prices' and 'weather conditions' to reviews and reports released 
periodically (e.g. weekly, quarterly). Nevertheless, it is a well-known fact that the smallholder agricultural communities in the country, especially in less-developed rural areas, have persistently suffered from those issues related to receipt of appropriate knowledge and information pertaining to agriculture (information on prices and consumer demand) on time and regular basis. This has mostly been due to the inefficiencies associated with the mode of dissemination (De Silva and Ratnadiwakara, 2008). At the level of the farm, the most farmers have inadequate access to and usage of the most important agricultural information needed for sustainable production (Lwoga et al., 2011). This will eventually lead to the dismal growth of the agricultural sector and prevalence of poverty among households whose livelihoods rely solely on agriculture, and this also is a common phenomenon with Sri Lankan smallholder agriculture.

In light of these, the purpose of the study was to investigate the factors that trigger or hinder farmer access to agricultural knowledge and information. The smallholder agricultural farmers in the Kandy and Kurunegala districts in Sri Lanka were of special interest.

\section{MATERIALS AND METHODS}

Based on the literature referring to the previous studies on this area, the following conceptual framework (Figure 1) was constructed that depicts the relationship between a number of factors that govern farmer access to agricultural information, including their demographic and perceptions, market information and accessibility and also the information repository issues.

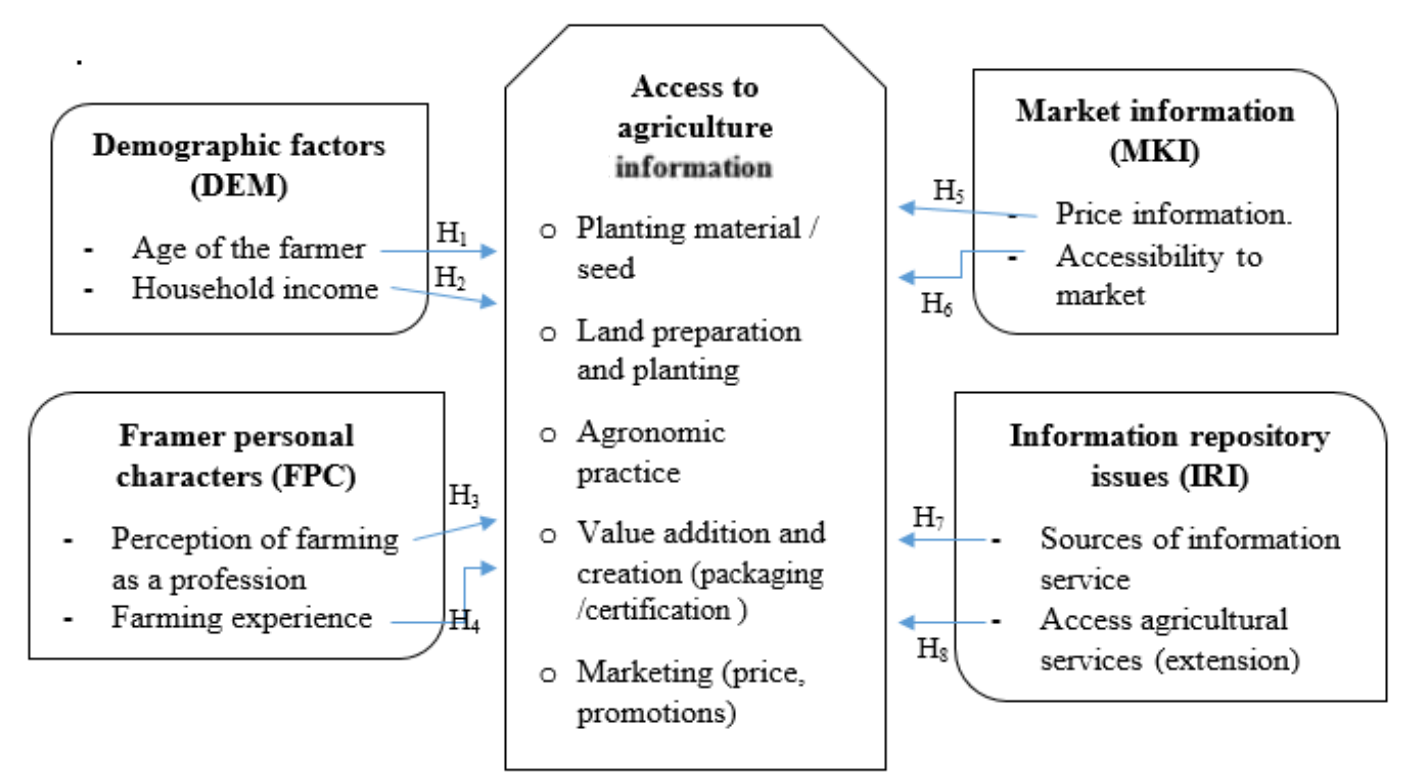

Figure 1. Conceptual Framework 
Based on this framework we may hypothesize that 'farmer access to agricultural knowledge through valid and reliable information at the right time on regular basis' is significantly associated with his/her: (H1) age; (H2) household income; (H3) perception of farming as a profession; (H4) farming experience; (H5) price information; (H6) market accessibility; (H7): sources of information services, and (H8) access to agricultural services, including extension and officers.

\section{Study Area and Data}

The data for this study were gathered from multicultural agriculture communities involved with "Export Agriculture Crops (EAC) producers" under the guidance of the Department of Export Agriculture, the government organization responsible for EAC in the country. It works extensively in the geographical areas of Kandy, Poojapitiya and Doluwa Divisional Secretariats (DS) in Kandy district and Mallawapitiya and Redeegama DS Divisions in Kurunegala District. A series of the structured face-to-face interviewbased questionnaire was carried out with a cross-section of smallholder agriculture farmers ( $\mathrm{n}=132$ ) to collect primary information. The purposive sampling technique was used in selecting farmers and the 'LIRNEasia Teleuse@BOP4' (LIRNEasia, 2012) instrument was adopted in particular for the purpose of preparation of the questionnaire. This instrument especially focused to gather information pertaining to the agricultural knowledge needs, agricultural information-seeking patterns, major sources of agricultural knowledge, constraints on access to agricultural knowledge, and the socioeconomic and demographic data of the respondents in the study area.

Responses to most of the questions were obtained by way of a five-point Likertscale ranging from ' 1 ' (Strongly Disagree) to '5' (Strongly Agree). The validity and reliability of the data collected for the purpose were evaluated through Cronbach's alpha value, where the alpha closer to 1.0 indicates a "better", and in general, the values less than 0.6 indicate that reliability is "poor". Commonly, the values in 0.70 range are considered "acceptable" and those over 0.80 considered "good" (Sekaran, 2006). Prior to the extraction of the factors, the Keiser-Meyer-Olking test (KMO) was used to assess the sampling adequacy and Barlett's test of Sphericity used to assess the factorability of the data. The KMO index ranges from 0 to 1 , with 0.5 suggested as the minimum value for good analysis. The Barlett's test of Sphericity should, therefore, be significant $(p<0.05)$ for an analysis to be considered appropriate (Tobias, \& Carlson, 1969). The results obtained through statistical analyses were taken together with qualitative information obtained through a series of focus group discussions and on-farm/household personal observation.

\section{RESULTS AND DISCUSSION}

\section{Descriptive Statistics of Smallholder Farmers}


A vast majority (89 percent) of the smallholding farmers surveyed $(n=132)$ were 'Sinhalese' by nationality followed by the 'Muslims'. Further, 75 percent were 'Buddhists' by religion followed by the 'Christians' and 'Muslims' 14 and 11 percent respectively. Nearly 57 percent of farmers were males and the mean age of a farmer was 51 years. In fact, 54 percent of farmers in the sample were fallen within the age of 45 to 75 years. About 58 percent of farmers were classified under the income category of the lowest annual income, i.e. less than Rs. 180,000 per annum. In terms of the educational qualifications of farmers who participated in the survey, 55 percent had attained up to the secondary level followed by 22 percent up to the primary level. In fact, another 2 percent had not attained any formal education; however, this particular set of farmers has also been literate enough to communicate with others in the community verbally (Table 1 ).

\section{Needs, Acquisition and Usage of Knowledge and Information}

Kamba (2009) stated that any community of people, including those in agriculture, is not in a position to develop themselves

Table 1. Distribution of demographic data and use of agricultural knowledge

\begin{tabular}{|c|c|c|c|}
\hline Variable & Category & $\begin{array}{c}\text { Frequency } \\
\%\end{array}$ & $\begin{array}{c}\text { Use of } \\
\text { Agricultural } \\
\text { Knowledge / } \\
\text { Information \% }\end{array}$ \\
\hline \multirow[t]{2}{*}{ Sex } & Male & 57 & 96 \\
\hline & Female & 43 & 94 \\
\hline \multirow[t]{5}{*}{ Age (Years) } & $20-29$ & 14 & 100 \\
\hline & $30-44$ & 27 & 97 \\
\hline & $45-59$ & 36 & 96 \\
\hline & $60-75$ & 18 & 94 \\
\hline & $>75$ & 05 & 80 \\
\hline \multirow[t]{4}{*}{ Education } & $\begin{array}{l}\text { Literate but no } \\
\text { schooling }\end{array}$ & 02 & 60 \\
\hline & Grade 0 - 5 & 22 & 93 \\
\hline & Grade 6 -11 & 55 & 98 \\
\hline & $\begin{array}{c}\text { Advanced Level and } \\
\text { above }\end{array}$ & 21 & 100 \\
\hline \multirow[t]{3}{*}{ Religion } & Buddhist & 75 & 96 \\
\hline & Christians & 14 & 97 \\
\hline & Muslim & 11 & 95 \\
\hline \multirow{3}{*}{$\begin{array}{l}\text { Annual } \\
\text { household } \\
\text { income/per } \\
\text { annum }\end{array}$} & $<$ Rs. 180,000 & 58 & 96 \\
\hline & Rs. $180,000-360,000$ & 32 & 98 \\
\hline & $>$ Rs. 360,000 & 10 & 100 \\
\hline
\end{tabular}


overtime without acquiring a sufficient amount of knowledge, and in this respect, the information plays a vital role by working as a vehicle of transforming and accumulating the knowledge. To explore the validity of this fact, the respondents were inquired particularly about the necessity and level of utilization of agricultural knowledge and information on their long-term and day-to-day agricultural operations. It has been found that more than 95 percent of smallholding farmers badly needed and also heavily used agricultural knowledge and information in this respect (Table 1).

Adeogun et al. (2010) stated that younger farmers, as compared to their counterpart, i.e. older farmers, are more likely to spend their time to access new information from improved technologies. This fact has also been proved in our sample where "young" farmers (i.e. age 20-29 years) fall into the "most" educated category (i.e. >Advanced Level) and they have requested and used agricultural information and the knowledge more than others in their farming activities. In other words, the demand for valid and reliable agriculture knowledge and information has slightly been decreased as the farmers become "old" and "less educated".

Each farmer interviewed was asked to indicate the type of agriculture-related knowledge and information that they "need", and the amount that they "acquired" in reality. A list of factors that was produced for them included agricultural support programs (credit/ subsidy/loan)
(ASL), sustainable agronomic practices (SAP), land preparation (LDP), pest and disease control (PDC), seed/variety selection (SVS), postharvest handling (PHH), fertilizer application (FTA) and crop market price (CMP). The summary of the outcome is depicted in Figure 2.

It shows that farmers were more concerned about the accurate and timely information about the market prices of the crops that they cultivated (CMP $=96 \%$ ) followed by other information needs such as agricultural subsidies/loan schemes (ASL = 95\%), the methods that can be used to control pests and diseases (PDC $=92 \%$ ), and the recommendations and application of fertilizer $($ FTA $=85 \%)$. Further, the gap between information need and receipt was highest in market prices of crops (CMP), agricultural support programs (ASL), and sustainable agronomic practices (SAP) suggesting that the farmers, in general, have been experiencing inadequate access to the most important agricultural information over time.

\section{Sources of Information in Use to Gain Agricultural Knowledge}

Another important aspect considered in the analysis was the major sources of agricultural information used by the farmers. To reveal this phenomenon, a number of such sources were considered, including from the government officers (extension officers and regional development officers), farmer organizations/society, market vendors, 


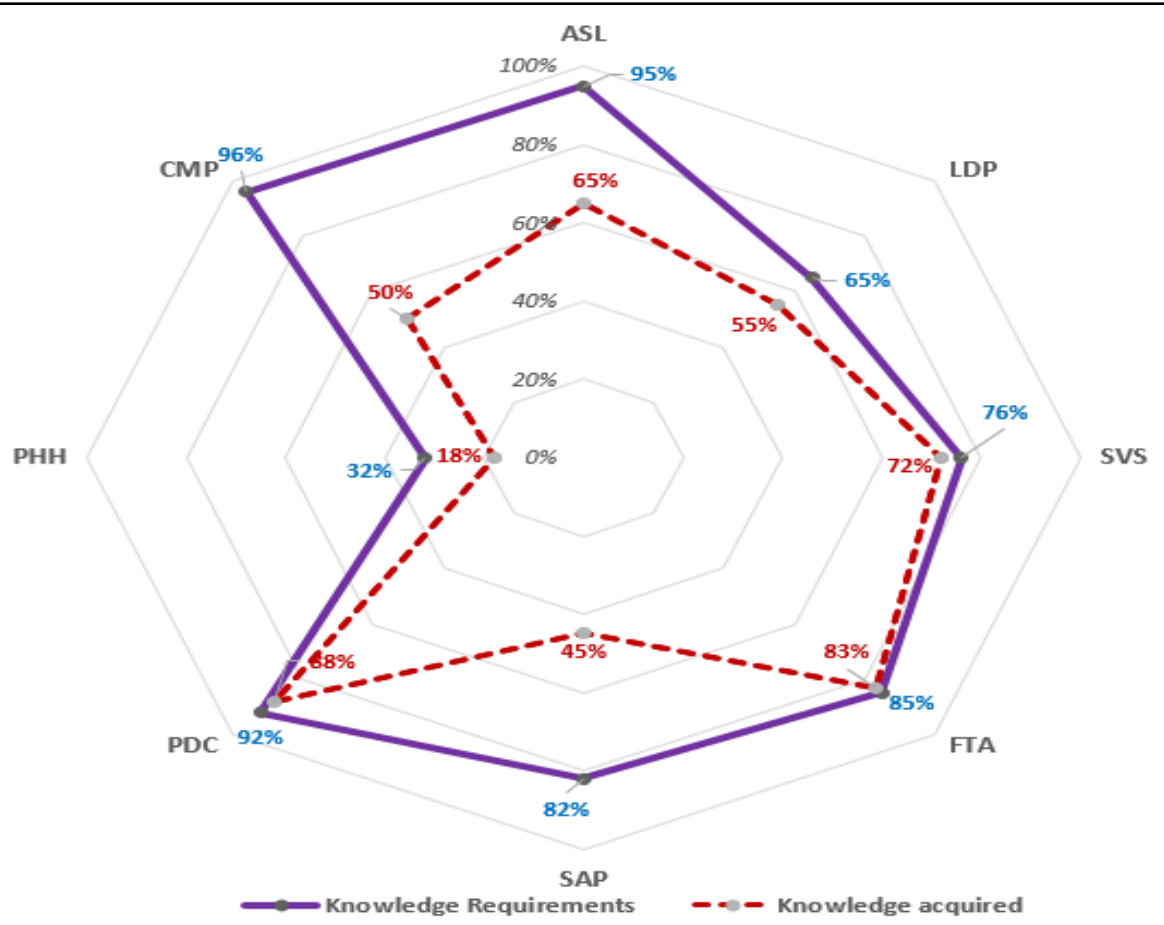

ASL - agricultural subsidy/loan, LDP - land preparation, SVS - seed / variety selection, FTA - fertilizer application, SAP - sustainable agronomic practices, PDC - pest and disease control, $\mathrm{PHH}$ - post harvest handling, CMP - crop market price.

Figure 2. Type of agriculture related information expected and acquired by the surveyed communities.

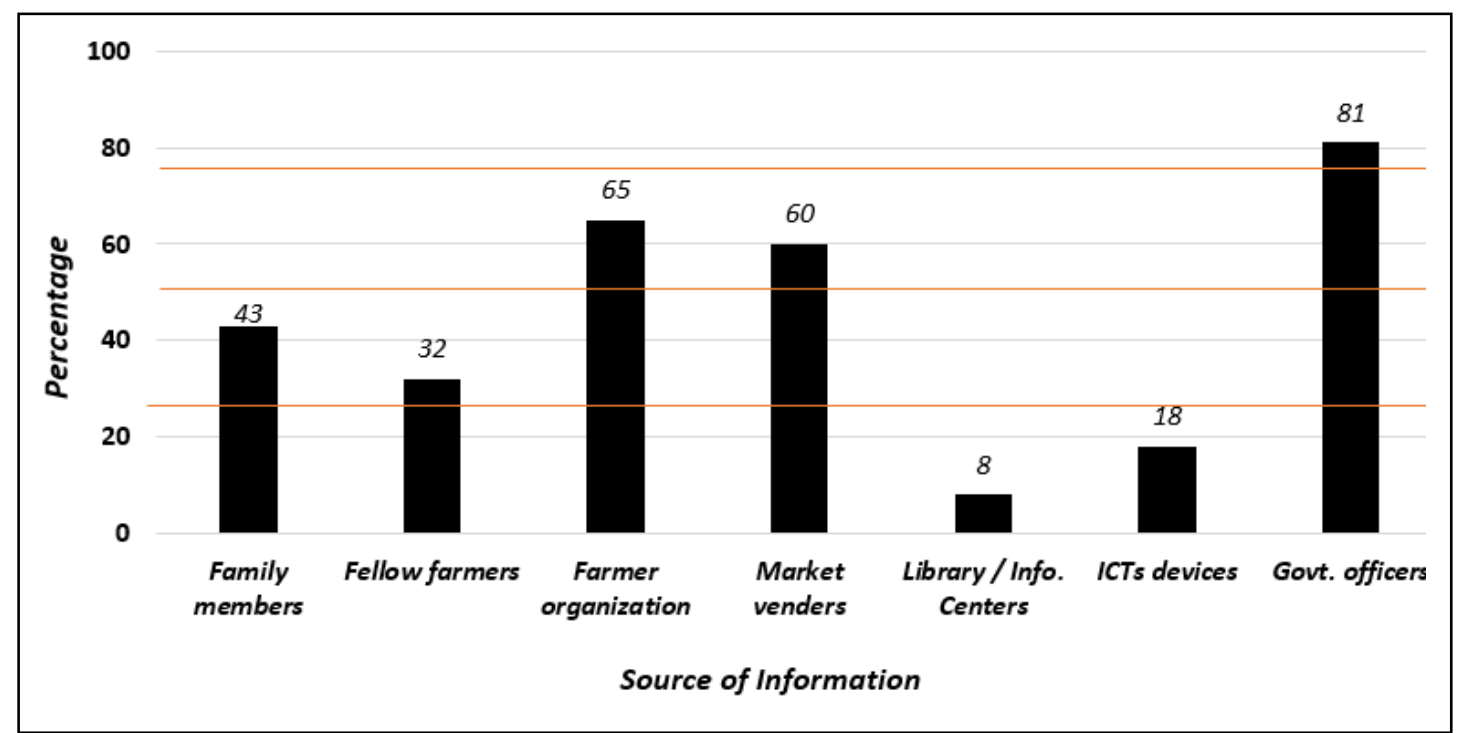

Figure 3. Different sources of agriculture information seeking by the farmers ( $\mathrm{n}=95$ ) 
family members, fellow farmers, library/information centre, and ICT related devices (Figure 3). The results show that the most popular sources of information include government officers (81\%), followed by farmer organizations (65\%) and market vendors (60\%). The least popular ways and means include ICT devices (18\%) and library/information centres (8\%).

The respondents were asked to indicate the factors that limit their access to agricultural information. The eight key aspects included in the conceptual framework were selected specifically for this purpose.

These were subjected to a number of statistical analyses to verify their validity and reliability. It was found that Cronbach's alpha value of all factors (Scale reliability coefficient $=0.687$ ), except the perception of farming as a career, resulted in more than 0.60 . The adequacy of the sample was measured using KMO and Barlett's test of sphericity. The KMO value was 0.672, which is greater than the rule of thumb 0.50 , and Barlett's test of sphericity also was significant $(\mathrm{P}=0.001)$.

The results show that the lack of sources of information services (93\%), lack of agricultural officers, i.e. extension officer and regional development officer (87\%), farmers age (80\%), price information (price of seed, planting material, fertilizer, pesticide, market price, etc. (76\%), and market accessibility (58\%) were the key constraints faced by farmers, in general (Table 2).

Table 2: Summary statistics of the factors that limit the access to agricultural information

\begin{tabular}{|c|c|c|c|c|c|c|c|}
\hline \multirow[t]{2}{*}{ Category } & \multirow[t]{2}{*}{ Factors } & \multicolumn{3}{|c|}{ Frequency \% } & \multirow{2}{*}{$\begin{array}{l}\text { Cronbach's } \\
\text { Alpha Value }\end{array}$} & \multirow[t]{2}{*}{$\mathbf{Z}$} & \multirow{2}{*}{$\mathbf{P}>|\mathbf{Z}|$} \\
\hline & & 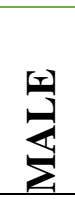 & 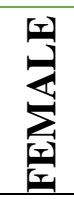 & $\begin{array}{l}\text { 是 } \\
0 \\
0\end{array}$ & & & \\
\hline \multirow[t]{2}{*}{ DEM } & Age of the farmer & 76 & 84 & 80 & 0.825 & $2.43 *$ & 0.0219 \\
\hline & Household income & 48 & 40 & 43 & 0.524 & 4.21 & 0.0684 \\
\hline \multirow[t]{2}{*}{ FPC } & $\begin{array}{l}\text { Perception of } \\
\text { farming as a career }\end{array}$ & 32 & 26 & 28 & 0.312 & 4.41 & 0.0725 \\
\hline & Farming experience & 76 & 52 & 63 & 0.741 & $2.95 *$ & 0.0366 \\
\hline \multirow[t]{2}{*}{ MKI } & Price information & 76 & 76 & 76 & 0.725 & $3.13^{*}$ & 0.0472 \\
\hline & $\begin{array}{l}\text { Accessibility to } \\
\text { market }\end{array}$ & 73 & 55 & 70 & 0.611 & $2.78 *$ & 0.0345 \\
\hline \multirow[t]{2}{*}{ IRI } & $\begin{array}{l}\text { Sources of } \\
\text { information service }\end{array}$ & 89 & 96 & 93 & 0.893 & $2.55^{*}$ & 0.0271 \\
\hline & $\begin{array}{l}\text { Access agricultural } \\
\text { services (extension) }\end{array}$ & 82 & 90 & 87 & 0.861 & $2.61 *$ & 0.0298 \\
\hline
\end{tabular}


A Logistic regression model was employed to see the relationship between those constraints considered in Table 2 and the farmers' access to agricultural knowledge and information.

The model was significant with Pvalue of 0.0001 given by Likelihood Ratio Chi-square of 49.86. Out of the eight hypotheses specified to reflect those factors in the conceptual framework, the hypotheses of H1, H4, H5, H6, H7 and H8 were statistically significant, while $\mathrm{H} 2$ and H3 were not statistically significant.

The results, overall, implies that farmer's level of age, poor information services in the area, availability of agricultural officers, farmer experience, price information and market accessibility possess a significant effect on the farmers' access to agricultural knowledge and information.

\section{CONCLUSION}

The findings of the study show that almost ninety-five percent of EAC producers in Kandy and Kurunegala have access and utilize agricultural knowledge and information in their farming-related activities. Amongst the other factors, those farmers, in general, need badly the valid and reliable agricultural information on a regular basis with regard to the market prices of inputs and outputs, credits/subsidies/loans etc. available and the measures of crop protection, i.e. pests and disease control.
The inadequacy in information services and agricultural officers, limited infrastructure and insufficient funds/resources hinder effective farmer access to agricultural knowledge and information. In light of these, it is utmost important that information providers, both private and public, identify all these challenges, and in turn, provide farmers with convenient and economical access to valid and reliable agricultural knowledge and information. It is utmost important that the information needed by rural farmers is repackaged in a language that they can understand and offer them at the appropriate time.

There is a need for government and other responsible institutions to emphasis on sustainable practices for information accessibility to smallholder farmers and also to disseminate information to them and address their information needs properly. From the policy point of view, the outcome of the analysis overall highlights the importance of developing appropriate packages to facilitate information sharing and knowledge mobilization in need with the right mix of market-based and regulatory incentives.

\section{ACKNOWLEDGMENT}

This project is made possible through the funding from the Wayamba University of Sri Lanka (SRHDC/RP/ 04/18-06).

\section{REFERENCES}

Adeogun, S.O., Olawoye, J.E. and Akinbile, L.A. (2010). Information 
Sources to Cocoa Farmers on Cocoa Rehabilitation Techniques (CRTs) in Selected States of Nigeria, Journal Media and Communication Studies, 2(1): 9 -15.

Bawa, B.D. and Bzugu, P.M. (2014). Influence of Sources of Information on Maize Farmers in Southern Borno, Nigeria. New Media and Mass Communication Paper, 31(2): 22243267.

Central Bank (2015). Annual report, Central Bank of Sri Lanka, Colombo.

De Silva, H., and Ratnadiwakara, D. (2008). Using ICT to Reduce Transaction Costs in Agriculture Through Better Communication: A Case-Study from Sri Lanka. LIRNEasia, Colombo, Sri Lanka. Available from http://www.lirne asia.net/wp-content/uploads/2008/11/tr ansactioncosts.pdf (verified $20^{\text {th }}$ Oct. 2018)

Frické, M. (2009). The Knowledge Pyramid: A Critique of the DIKW Hierarchy, Journal of Information Science. 35(2): 131-142.

Galadima, M. (2014). Constraints on Farmers Access to Agricultural Information Delivery: A Survey of Rural Farmers in Yobe State, Nigeria. Journal of Agriculture and Veterinary Science, 7(9): 18-22.

Kamba, A.K. (2009). Access to Information: The Dilemma for Rural Community Development in Africa. Available from http://globelics2009dak ar.merit.unu.edu/papers/1238296264_ M A.pdf (verified $10^{\text {th }}$ Feb. 2019)

LIRNEasia, (2012). Teleuse at the Bottom of the Pyramid 4 (Teleuse@BOP4). Available from http://lirneasia.net/proj ects/2010-12-research-program/ teleuse bop4. (verified $19^{\text {th }}$ Dec. 2018)
Lwevo, E., Onyango, C.A., Udoto, M. O. and Digo, C. A. (2014). Selected Cultural Factors Influencing Access to Agricultural Extension Services Among Pastoralists in Wajir County, Kenya. Journal of International Academic Research for Multidisciplinary, 2(5): 547-559.

Lwoga, E. T., Stilwell, C. and Ngulube, P. (2011). Access and Use of Agricultural Information and Knowledge in Tanzania, Library Review. 60(5): 383395.

Mtega, W. P., Ngoepe, M. and Dube, L. (2016). Factors Influencing Access to Agricultural Knowledge: the Case of Smallholder Rice Farmers in the Kilombero District of Tanzania. South African Journal of Information Management. 18(1): 1-8.

Nazari, M.R., Bin, H.J. and Hassan, S. (2011). The Role of Television in the Enhancement of Farmers Agricultural Knowledge, African Journal of Agricultural Research. 6(4): 931-936.

Rehman, F., Muhammad, I and Ashraf, I., (2013). Effect of farmers' Socioeconomic Characteristics on Access to Agricultural Information: Empirical Evidence from Pakistan. The Journal of Animal and Plant Sciences, 23(1): 324-329.

Sekaran, U. (2006). Research Methods for Business: A Skill-Building Approach. John Wiley \& Sons.

Tobias, S., and Carlson J. E. (1969). Brief Report: Bartlett's Test of Sphericity and Chance Findings in Factor Analysis. Multivariate Behavioural Research, 4(3): 375-377. 